International Journal of Current Advanced Research

ISSN: O: 2319-6475, ISSN: P: 2319 - 6505, Impact Factor: SJIF: 5.995

Available Online at www.journalijcar.org

Volume 6; Issue 3; March 2017; Page No. 2977-2979

DOI: http://dx.doi.org/10.24327/ijcar.2017.2979.0159

Research Article

\title{
ANTIBACTERIAL EFFECT OF GARLIC EXTRACT ON GROWTH OF STAPHYLOCOCCUS AUREUS
}

\author{
*Ilankizhai RJ., Geetha RV and Shubha
}

${ }^{1}$ Saveetha Dental College and Hospitals, Saveetha university, Chennai -600077

${ }^{2}$ '3 Department of Microbiology, Saveetha Dental College and

Hospitals, Saveetha university, Chennai -600077

\begin{tabular}{l} 
A R T I C L E I N F O \\
\hline Article History: \\
Received $25^{\text {th }}$ December, 2016 \\
Received in revised form $15^{\text {th }}$ January, 2017 \\
Accepted $16^{\text {th }}$ February, 2017 \\
Published online $28^{\text {th }}$ March, 2017
\end{tabular}

Key words:

Effect of Garlic Extract, Staphylococcus Aureus

\begin{abstract}
A B S T R A C T
Objective: The aim of the present study is to evaluate the antibacterial activity of fresh garlic juice using in vitro techniques, against staphylococcus aureus bacteria.

Materials And Method: The Staphylococcus aureus was obtained from the Department of microbiology, Saveetha Dental College, Chennai.In the present study, we are using fresh garlic juice as a form of garlic extract to analyse the antibacterial effect of garlic extract on Staphylococcus aureus. The antibacterial effect of garlic extract was tested by agar well diffusion method.

Results: The crude garlic extract showed favourable results against Staphylococcus aureus even in varying concentrations. The crude Allium sativum extract produced a mean zone of inhibition of $41 \mathrm{~mm}$ with $100 \%, 18 \mathrm{~mm}$ and $30 \mathrm{~mm}$ with $25 \%$ and $50 \%$ extract respectively.

Conclusion: It can be generally concluded that the obtained results indicate the effectiveness of crude Allium sativum (garlic) extract as an antibacterial agent against Staphylococcus aureus.
\end{abstract}

Copyright $@ 2017$ Ilankizhai RJ., Geetha RV and Shubha. This is an open access article distributed under the Creative Commons Attribution License, which permits unrestricted use, distribution, and reproduction in any medium, provided the original work is properly cited.

\section{INTRODUCTION}

Microbial pathogenecity and other infectious diseases have been controlled by use of commercially available antimicrobial drugs since last many years. (1) Excessive usage of antibiotics has led to the development of multiple drug resistance (MDR) in many bacterial pathogens. The increasing drug resistance is the main hindrance in successful treatment of infectious diseases. (2) Development of drug resistance in pathogens forces us to explore newer natural antibiotic agents. Natural products are a major source of new natural drugs and their use as an alternative medicine for treatment of various diseases has been increased in the last few decades. (3) Plants as a source of medicines and drugs have continued to play a vital role in the maintenance of human health since time immemorable.

Allium sativum commonly known as garlic is an odoriferous plant belonging to a family lilacease.Throughout history, many different cultures have recognised the potential use of garlic for prevention and treatment of different diseases.(4) The most commonly used parts of garlic are its bulb and cloves. Allium sativum has not only been recognised

*Corresponding author: Ilankizhai RJ

Saveetha Dental College and Hospitals, Saveetha

University, Chennai -600077 as a spice but also as a substance which exerts control on microorganisms.(5) Recent studies indicate that garlic extract has a broad spectrumof antimicrobialactivity against numerous genera of bacteria and fungi. The antibacterial effect of garlic extract is primarily due to the presence of extensive amounts of sulphur containing compounds, the major one being allicin. Allicin is produced by the enzymatic (alliin lyase) hydrolysis of allicin after cutting and crushing of the cloves.(4) Alliin lyase is a major product of the storage bud (clove), accounting for $10 \%$ of its total protein.(6) These compounds are found to be responsible for the odour, flavour and most of the pharmacological actions of garlic. Recent researches indicate that garlic extracts even have antihypertensive, antioxidant, anti-platelet, anti-tumour and lipid lowering actions along with their exclusive antibacterial actions.Because many of the microorganisms susceptible to garlic extract are medically significant, garlic holds a promising position as a broad-spectrum therapeutic agent. (5) The objective of the present study is to evaluate the antibacterial activity of fresh garlic juice, against staphylococcus aureus bacteria.

\section{MATERIALS AND METHODS}

\section{Source of Bacterial Strains}

The Staphylococcus aureus was obtained from the Department of microbiology, Saveetha Dental College, Chennai. 


\section{Preparation of Garlic Extract}

In the present study, we are using fresh garlic juice as a form of garlic extract to analyse the antibacterial effect of garlic extract on Staphylococcus aureus. $100 \mathrm{~g}$ of fresh garlic were purchased from the local market. The cloves were peeled, and cleaned. The garlic cloves were surface sterilised by immersing them into laboratory grade ethanol for 60 seconds. The residual ethanol was allowed to evarporate. This was followed by homogenising the mixture aseptically in sterile mortar and pestle. The homogenised mixture was filtered through sterile cheesecloth.this extract was considered as the $100 \%$ concentration of the extract (4). The concentration was further diluted with appropriate sterile distilled water to obtain $25 \%$ and $50 \%$ concentration of the extract.

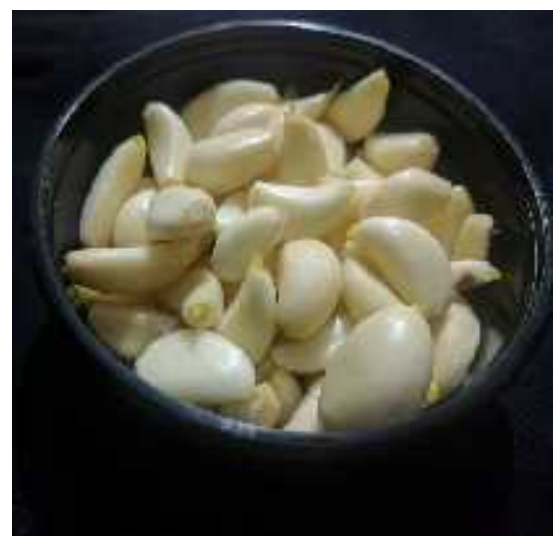

Figure 1 garlic cloves peeled and cleaned

\section{Testing of antibacterial activity using agar well diffusion method}

Broth cultures of the test organism compared to Mac Farland's standard 0.5 were prepared. Lawn cultures of the test organism were made on the Muller-Hinton agar [MHAM1084] plates using sterile cotton swab and the plates were dried for 15 minutes. Well measuring $4 \mathrm{~mm}$ depth was made on the agar with sterile cork borer. $100 \mu$ of the extract of $100 \%, 50 \%$, and $25 \%$ concentration were added to the wells. The plates were incubated overnight and the zone of inhibition of growth was measured in mm diameter. All the tests were done in duplicate to minimise the error. $(7,8,9)$

\section{RESULTS}

The investigation of antibacterial activity of crude garlic extract against, Staphylococcus aureus was done by agar well diffusion method. (5)Mean zones of inhibition of different concentrations were measured by agar well diffusion assay and compared with the control. The mean zones of inhibition of diiferent concentrations of crude garlic extract on Staphylococcus aureus along with control is recorded and tabulated in table 1.

Table 1 The mean zones of inhibition of different concentration of crude garlic extract on Staphylococcus aureus.

\begin{tabular}{ccc}
\hline Concentration (\%) & $\begin{array}{c}\text { Allium sativum } \\
\text { Zone Of Inhibition }\end{array}$ & Control \\
\hline 25 & $18 \mathrm{~mm}$ & \\
50 & $30 \mathrm{~mm}$ & $36 \mathrm{~mm}$ \\
100 & $41 \mathrm{~mm}$ & \\
\hline
\end{tabular}

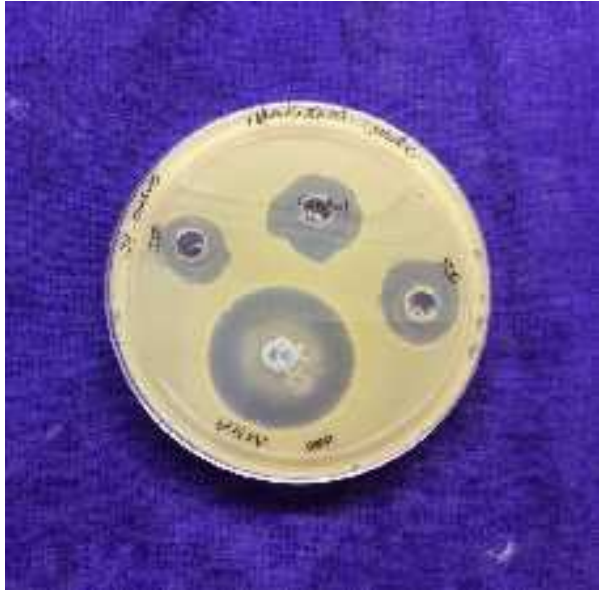

Figure 2 Zones of inhibition different concentration of crude garlic extract on Staphylococcus aureus.

The crude garlic extract showed favourable results against Staphylococcus aureus even in varying concentrations. Staphylococcus aureus showed maximum susceptibility towards $100 \%$ garlic extract with a zone of inhibition of 41 $\mathrm{mm}$ which is greater than the zone of inhibition produced by the control.The crude Allium sativum extract produced a mean zone of inhibition of $18 \mathrm{~mm}$ and $30 \mathrm{~mm}$ with $25 \%$ and $50 \%$ extract respectively.

\section{DISCUSSION}

Since time immemorable, microbial pathogenicity and infectious diseases have been treated by commercially available antibiotics. Tremendous use of antibacterial agents has led to the development of multiple drug resistance in many pathogenic bacteria. Staphylococcus aureusis one such pathogenic bacteria which has developed resistance to many of the antibacterial agents commercially available.This drug resistance serves as an obstacle in the successful treatment of staphylococcal infections including skin infections such as a skin abscess, respiratory infections such as sinusitis, and food poisoning.T he emergence of antibiotic-resistant strains of S. aureus such as methicillin-resistant S. aureus (MRSA) is a worldwide problem in clinical medicine.This forces us to explore newer natural antibacterial agents.Garlic is something which is being consumed every day, but its effectiveness as an antibacterial agent against Staphylococcus aureus is less known. The findings of the study reveal that the crude Allium sativum (garlic) extract produced a zone of inhibition of 41 $\mathrm{mm}$ at $100 \%$ concentration which is greater than the zone of inhibition produced by the control.

\section{CONCLUSION}

It can be generally concluded that the obtained results indicate the effectiveness of crude Allium sativum (garlic) extract as an antibacterial agent against Staphylococcus aureus. Hence this shows the possibility of using Allium sativum (garlic) extract as an alternative to the antibacterial agents to which Staphylococcus aureus has developed resistance. The use of garlic extract proves to be solely beneficial.

\section{References}

1. Iram GullEmail author, Mariam Saeed, Halima Shaukat, Shahbaz M Aslam, Zahoor Qadir Samra and Amin M Athar, Inhibitory effect of Allium sativum 
and Zingiberofficinale extracts on clinically important drug resistant pathogenic bacteria, Annals of Clinical Microbiology and Antimicrobials 201211:8DOI: 10.1186/1476-0711-11-8@ Gull et al.; licensee BioMed Central Ltd. 2012

2. 1. Fu YJ, Zu YG, Chen LY, Shi XHG, Wang Z, Sun $\mathrm{S}$, Efferth T: Antimicrobial Activity of clove and rosemary essential oils alone and in combination. Phytother Res. 2007, 21: 989-999. 10.1002/ptr.2179

3. Vuorelaa P, Leinonenb M, Saikkuc P, Tammelaa P, Rauhad JP, Wennberge T, Vuorela H: Natural products in the process of finding new drug candidates. Curr Med Chem. 2004, 11: 1375-1389.

4. Palaksha MN, Ahmed M, Das S. Antibacterial activity of garlic extract on streptomycin-resistant Staphylococcus aureus and Escherichia coli solely and in synergism with streptomycin. Journal of Natural Science, Biology, and Medicine. 2010;1(1):12-15. doi:10.4103/0976-9668.71666.
5. Adetumbi, Moses A et al. Allium sativum (garlic) -A natural antibiotic

Medical Hypotheses, Volume 12, Issue 3, 227 - 237

6. Ellmore GS, Feldberg RS. Alliin lyase localization in bundle sheaths of garlic cloves (Allium sativum Linn) Am J Bot. 1994;81:89-94. [Ref list]

7. M. Pooja Umaiyal et al, Anti Microbial Activity of Jojoba Oil against Selected Microbes: An Invitro Study,/J. Pharm. Sci. \& Res. Vol. 8(6), 2016, 528-529

8. Faazila Fathima, Vishnu Priya V. and Geetha R. V., Evaluation of antimicrobial activity of lavender oil against selected bacterial pathogens: An in vitro study, Journal of Chemical and Pharmaceutical Research, 2015, 7(12):624-626

9. Sweta $v$, geetha $r$ v2, in vitro antibacterial activity of clove and pepper on streptococcus mutans,Asian journal of pharmaceutical and clinical research. $\mathrm{Vol}$ 8, Issue 5, 2015

Please cite this article in press as:

Ilankizhai RJ., Geetha RV and Shubha (2017), 'Antibacterial effect of garlic extract on growth of staphylococcus aureus', International Journal of Current Advanced Research, 6(3), pp. 2977-2979.

http://dx.doi.org/10.24327/ijcar.2017. 2979.0159 